University of Nebraska - Lincoln

DigitalCommons@University of Nebraska - Lincoln

\title{
Root biomass, root/shoot ratio, and soil water content under perennial grasses with different nitrogen rates
}

\author{
Upendra M. Sainju
}

USDA-ARS, upendra.sainju@ars.usda.gov

Brett L. Allen

USDA-ARS, brett.allen@ars.usda.gov

Andrew W. Lenssen

lowa State University, alenssen@iastate.edu

Rajan P. Ghimire

New Mexico State University, rghimire@nmsu.edu

Follow this and additional works at: https://digitalcommons.unl.edu/usdaarsfacpub

Sainju, Upendra M.; Allen, Brett L.; Lenssen, Andrew W.; and Ghimire, Rajan P., "Root biomass, root/shoot ratio, and soil water content under perennial grasses with different nitrogen rates" (2017). Publications from USDA-ARS / UNL Faculty. 1849.

https://digitalcommons.unl.edu/usdaarsfacpub/1849

This Article is brought to you for free and open access by the U.S. Department of Agriculture: Agricultural Research Service, Lincoln, Nebraska at DigitalCommons@University of Nebraska - Lincoln. It has been accepted for inclusion in Publications from USDA-ARS / UNL Faculty by an authorized administrator of DigitalCommons@University of Nebraska - Lincoln. 


\title{
Root biomass, root/shoot ratio, and soil water content under perennial grasses with different nitrogen rates
}

\author{
Upendra M. Sainju $^{\mathrm{a}, *}$, Brett L. Allen ${ }^{\mathrm{a}}$, Andrew W. Lenssen ${ }^{\mathrm{b}}$, Rajan P. Ghimire ${ }^{\mathrm{c}}$ \\ a USDA, Agricultural Research Service, Northern Plains Agricultural Research Laboratory, 1500 North Central Avenue, Sidney, MT, 59270, USA \\ b Department of Agronomy, Iowa State University, Ames, IA 50011, USA \\ ${ }^{\mathrm{c}}$ New Mexico State University, Agricultural Science Center, Clovis, NM 88101, USA
}

\section{A R T I C L E I N F O}

\section{Keywords:}

Bioenergy crops

Perennial grasses

Nitrogen fertilization

Root biomass

Root/shoot ratio

Soil water

\begin{abstract}
A B S T R A C T
Roots help in soil water and nutrient uptake and provide carbon (C) input for soil C sequestration, but information on root biomass of bioenergy perennial grasses is lacking. Root/shoot ratios are used to estimate crop root biomass and $\mathrm{C}$ inputs, but the values for perennial grasses are also scanty. We examined root biomass, root/ shoot ratios, and soil water contents to a depth of $120 \mathrm{~cm}$ after grass harvest in the fall for three bioenergy perennial grasses applied with four nitrogen (N) fertilization rates from 2011 to 2013 in the northern Great Plains, USA. Perennial grasses were intermediate wheatgrass (Thinopyrum intermedium [Host] Barkworth and Dewey), smooth bromegrass (Bromus inermis L.), and switchgrass (Panicum virgatum L.), and N fertilization rates were $0,28,56$, and $84 \mathrm{~kg} \mathrm{~N}^{-1}$. Root biomass declined with depth and about $60 \%$ of the total biomass was located at $0-15 \mathrm{~cm}$ where intermediate wheatgrass and switchgrass had higher biomass than smooth bromegrass in 2011. Shoot biomass was greater in intermediate wheatgrass in 2011 and in switchgrass in 2013 than other grasses and increased with increased $\mathrm{N}$ rates. Root/shoot ratio was greater in switchgrass than other grasses at 0-120 cm in 2011, but was greater in smooth bromegrass than switchgrass at 0-60, 0-90, and 0-120 cm in 2012 and 2013. Mean root/shoot ratios across $\mathrm{N}$ rates and years were not different among grasses and varied from 1.54 at $0-15 \mathrm{~cm}$ to 2.54 at $0-120 \mathrm{~cm}$, which were substantially greater than 0.15 and 0.33 , respectively, observed for spring wheat (Triticum aestivum L.). Soil water content increased with depth and was greater under switchgrass than other grasses at $0-120 \mathrm{~cm}$ in 2011 and 2013 . Water content varied with $\mathrm{N}$ rate at various soil depths and years. Root biomass was negatively correlated with soil water content $(\mathrm{r}=-0.56, P=0.03$, $\mathrm{n}=15$ ). Because of greater root and shoot biomass, intermediate wheatgrass reduced soil water content due to increased water uptake and will likely provide more $\mathrm{C}$ inputs for soil $\mathrm{C}$ sequestration from belowground biomass compared to smooth bromegrass and spring wheat.
\end{abstract}

\section{Introduction}

Perennial grasses, such as ligno-cellulosic feedstock materials, have been shown to be promising crops for bioenergy production (Pacala and Solocolow, 2004; USDOE, 2007). These grasses have additional advantages compared with food crops, such as corn (Zea mays L.), for producing bioenergy: (1) they reduce pressure for using food crops for bioenergy, (2) they use water, $\mathrm{N}$, and solar radiation more efficiently and require reduced amounts of chemicals, such as fertilizers, herbicides, and pesticides, (3) they can be easily grown on marginal lands, (4) they are more productive per unit land area, and (5) they recycle nutrients seasonally between roots and shoots (Pacala and Solocolow, 2004; USDOE, 2007).
Although production of shoot biomass has been known for various perennial grasses, relatively little information is available about root biomass. Roots absorb water and nutrients from the soil and support aboveground shoot growth whose yield depends on the growth of belowground root biomass (Merrill et al., 2002; Stone et al., 2001). As the aboveground biomass of crops is usually harvested for grain, hay, litter, or fuel, roots form the main component of $\mathrm{C}$ input for soil $\mathrm{C}$ sequestration (Paustian et al., 1997). Besides root biomass, rhizodeposit in the form of exudates, secretions, cap cells, lysates, and mucilages can also form important sources of C for enriching soil organic C (Hawes et al., 2003; Nguyen, 2003). Roots may play a dominant role in the soil C cycle (Gale et al., 2000; Puget and Drinkwater, 2001) and may have relatively greater influence on soil organic matter than the

\footnotetext{
Abbreviation: IW, intermediate wheatgrass; SB, smooth bromegrass (SB); SG, switchgrass; SW, spring wheat

* Corresponding author.

E-mail address: Upendra.sainju@ars.usda.gov (U.M. Sainju).
} 
aboveground plant biomass (Norby and Cotrufo, 1998).

One of the management practices to sequester atmospheric $\mathrm{CO}_{2}$ in agricultural and range soils and enrich soil organic matter is to plant perennial grasses either alone or in rotation with cereal crops (Paustian et al., 1997). The reason is that perennial grasses have higher root biomass that contributes more $\mathrm{C}$ to the soil than cereal crops (Paustian et al., 1997; Bollinder et al., 1997, 2002). Furthermore, the relatively undisturbed soil condition under perennial grasses reduces mineralization of soil organic matter and therefore favors soil C accumulation. Because of the difficulty of accurately measuring root biomass in the field due to high variability and tedious work of separating roots from the soil, measurement of root biomass, especially for perennial grasses, is often neglected (Bollinder et al., 2002). Other sources of variation in the measurement of root biomass include the soil sampling strategy employed, different sieve size used to separate roots from the soil affecting the quantification of root biomass, variation in root growth during the crop growing season making the sampling time critical, and age of the grass establishment (van Nordwijk et al., 1987; Amato and Pardo, 1994).

The root/shoot ratio at crop harvest is used to estimate root biomass and C input from belowground residue (Bollinder et al., 1997, 2002). Because of variations in root and shoot growth due to various soil and climatic conditions among regions and during different periods of crop growth, root/shoot ratios can vary for perennial grasses. Root/shoot ratios for perennial grasses have been mostly reported for pasture and natural grassland, which ranged from 0.57 to 6.25 in USA (Mo et al., 1992; Mortimer, 1992) and from 0.18 to 2.44 in other countries (Bray, 1963; Bollinder et al., 2002). The values also vary with the depth of soil sample collected for determining root biomass and age of grasses (Campbell and de Jong, 2001; Bollinder et al., 2002). For example, the root/shoot ratio of various perennial grasses can vary from 0.28 at $0-15 \mathrm{~cm}$ in the year of establishment to 2.33 at $0-45 \mathrm{~cm}$ in successive years (Bollinder et al., 2002).

Variations in root growth and distribution in the soil profile among crops can lead to differences in water and nutrient uptake by roots. Roots that grow near water and nutrient availability are usually dense, have large diameter, and are active in growth and resource uptake (Pierret et al., 2007). Only 10-30\% of the total root length of a given root system, however, is actively involved in water and nutrient uptake (Robinson, 1991). Water stress can extend roots to a greater soil depth for water uptake more in grasses than legumes or forbs, resulting in greater root biomass and therefore greater root/shoot ratio in grasses (Skinner and Comas, 2010). Culman et al. (2013) reported that soil water content to a depth of $1 \mathrm{~m}$ was lower with intermediate wheatgrass than winter wheat, suggesting that perennial grasses are more effective in water uptake from the soil profile than cereal crops.

Nitrogen fertilization can have a variable effect on shoot and root biomass of perennial grasses among various regions and years due to variations in soil and climatic conditions. Heggenstaller et al. (2009) found that $\mathrm{N}$ fertilization at $140 \mathrm{~kg} \mathrm{~N} \mathrm{ha}^{-1}$ maximized shoot and root biomass $(0-30 \mathrm{~cm})$ of switchgrass in the same proportion, after which both declined with increased $\mathrm{N}$ rate. As a result, the root/shoot ratio of switchgrass was unaffected by $\mathrm{N}$ fertilization rates. Ibrahim et al. (2016) reported that increased $\mathrm{N}$ rate increased switchgrass shoot biomass in the first year, but not in the second year. Increased $\mathrm{N}$ rate from 0 to $90 \mathrm{~kg} \mathrm{~N} \mathrm{ha}^{-1}$ enhanced root and shoot biomass, after which root biomass remained constant, but shoot biomass continued to increase with further increases in $\mathrm{N}$ rate in smooth bromegrass (Power, 1988).

Little is known about the effect of perennial grasses and $\mathrm{N}$ fertilization rates on root biomass and root/shoot ratio of grasses and their relationships with soil water content compared with cereal crops. Differences in root biomass growth due to variations in grass species and $\mathrm{N}$ rates may result in different $\mathrm{C}$ inputs for $\mathrm{C}$ sequestration and soil water acquisition. We evaluated root and shoot biomass, root/shoot ratio, and soil water content to a depth of $120 \mathrm{~cm}$ for various perennial grasses with different $\mathrm{N}$ fertilization rates and compared them with annual spring wheat applied with recommended N rate from 2011 to 2013 in eastern Montana, USA. Our objectives were to: (1) quantify root and shoot biomass and root/shoot ratios of bioenergy perennial grasses applied with 0-84 $\mathrm{kg} \mathrm{N} \mathrm{ha}^{-1}$, (2) compare root biomass and root/shoot ratio of perennial grasses and a cereal crop, and (3) relate these parameters with soil water content. We hypothesized that root and shoot biomass, root/shoot ratio, and soil water content vary with perennial grass species and $\mathrm{N}$ fertilization rates, and root biomass and root/shoot ratio will be greater, but soil water content will be lower for perennial grasses than for spring wheat.

\section{Materials and methods}

\subsection{Treatments and grass management}

Perennial grasses were established on 5\% sloping land on April 2009 and the study was conducted from 2011 to 2013 at the USDA Conservation District Farm, $11 \mathrm{~km}$ north of Culbertson, MT, USA. The soil in the experimental site was a Williams loam (fine-loamy, mixed, superactive, frigid, Typic Argiustoll), with $660 \mathrm{~g} \mathrm{~kg}^{-1}$ sand, $180 \mathrm{~g} \mathrm{~kg}^{-1}$ silt, $160 \mathrm{~g} \mathrm{~kg}^{-1}$ clay, $10.1 \mathrm{~g} \mathrm{~kg}^{-1} \mathrm{SOC}, 7.2 \mathrm{pH}$, and $1.27 \mathrm{Mg} \mathrm{m}^{-3}$ bulk density at the $0-15 \mathrm{~cm}$ depth during the initiation of the experiment in April 2009. Mean (115-yr average) monthly air temperature ranges from $-8{ }^{\circ} \mathrm{C}$ in January to $23^{\circ} \mathrm{C}$ in July and August and a mean annual precipitation of $341 \mathrm{~mm}, 80 \%$ of which occurs during the growing season (April to October). Previous cropping history (10 yr) at the site was continuous spring wheat under conventional tillage.

Perennial grasses included three grasses (intermediate wheatgrass, smooth bromegrass, and switchgrass) as the main plot (plot size, $12.2 \times 30.5 \mathrm{~m}$ ) treatment where $\mathrm{N}$ fertilizer was applied at four rates $\left(0,28,56\right.$, and $\left.84 \mathrm{~kg} \mathrm{~N} \mathrm{ha}^{-1}\right)$ as the split-plot (plot size, $\left.3.1 \times 30.5 \mathrm{~m}\right)$ treatment. Intermediate wheatgrass and smooth bromegrass are coolseason grasses, whereas switchgrass is a warm-season grass. Treatments were arranged in a randomized complete block design with four replications. For this study, because of physical constraints, only three replications based on uniform slope with reduced spatial variability were considered. At the time of grass establishment in late April 2009, monoammonium phosphate $(11 \% \mathrm{~N}, 23 \% \mathrm{P})$ at $280 \mathrm{~kg} \mathrm{ha}^{1}$ was broadcast, which supplied $\mathrm{N}$ at $31 \mathrm{~kg} \mathrm{Nha}^{-1}$ and $\mathrm{P}$ at $64 \mathrm{~kg} \mathrm{P}^{-1}$. Immediately after fertilization, plots were cultivated using conventional tillage with a field cultivator to a depth of $7-8 \mathrm{~cm}$ for seedbed preparation and weed control. Using a no-till drill, intermediate wheatgrass, smooth bromegrass, and switchgrass were planted at 17,24 , and $17 \mathrm{~kg} \mathrm{ha}^{-1}$, respectively, at $20 \mathrm{~cm}$ spacing following tillage. In April, $2011-2013$, $\mathrm{N}$ fertilizer at $0-84 \mathrm{~kg} \mathrm{~N} \mathrm{ha}^{-1}$ as urea $(46 \% \mathrm{~N})$ was broadcast at the soil surface in split plots. No K fertilizer and irrigation were applied. Depending on the shoot growth, aboveground biomass was harvested at $5 \mathrm{~cm}$ above the ground one to two times a year (July and October) from two $0.5 \mathrm{~m}^{2}$ areas by hand, randomly within the plots and composited. A subsample was oven-dried at $60{ }^{\circ} \mathrm{C}$ for $3 \mathrm{~d}$ to determine dry matter yield, from which shoot yield was determined. Total shoot yield in a year was determined by adding yields from individual cuttings.

For comparing above- and belowground biomass of grasses with cereal crop, spring wheat was planted in a nearby area outside grass plots in April 2013. Wheat was planted at $71 \mathrm{~kg} \mathrm{ha}^{-1}$ under no-tillage using a no-till drill as above in three plots (plot size, $3.1 \times 30.5 \mathrm{~m}$ ) as three replications. Nitrogen fertilizer as urea and monoammonium phosphate at $100 \mathrm{~kg} \mathrm{~N}^{-1}$, P fertilizer as monoammonium phosphate at $29 \mathrm{~kg} \mathrm{P} \mathrm{ha}^{-1}$, and $\mathrm{K}$ fertilizer as muriate of potash $(52 \% \mathrm{~K})$ at $47 \mathrm{~kg} \mathrm{~K} \mathrm{ha}^{-1}$ were banded $5 \mathrm{~cm}$ to the side and $5 \mathrm{~cm}$ below the seed at planting. Herbicides and pesticides were applied as needed before and during crop growth. In August 2013, wheat was harvested from two $0.5 \mathrm{~m}^{2}$ areas by hand, randomly within the plot as above, separated into grain and vegetative biomass, oven dried at $60{ }^{\circ} \mathrm{C}$ for $3 \mathrm{~d}$, and yields 
Table 1

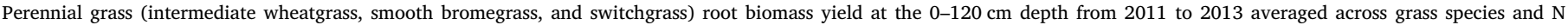
fertilization rates.

\begin{tabular}{|c|c|c|c|c|c|c|}
\hline \multirow[t]{2}{*}{ Year } & \multicolumn{6}{|c|}{ Root biomass $\left(\mathrm{Mg} \mathrm{ha}^{-1}\right)$} \\
\hline & $0-15 \mathrm{~cm}$ & $15-30 \mathrm{~cm}$ & $30-60 \mathrm{~cm}$ & $60-90 \mathrm{~cm}$ & $90-120 \mathrm{~cm}$ & $0-120 \mathrm{~cm}$ \\
\hline 2011 & $11.90 \mathrm{a}^{\mathrm{a}}$ & $1.19 \mathrm{~b}$ & $1.96 \mathrm{~b}$ & 1.28 & 0.48 & $16.81 \mathrm{a}$ \\
\hline 2012 & $7.27 b$ & $1.58 \mathrm{a}$ & $1.96 \mathrm{~b}$ & 1.16 & 0.59 & $12.56 \mathrm{~b}$ \\
\hline 2013 & $7.54 \mathrm{~b}$ & $1.70 \mathrm{a}$ & $3.24 \mathrm{a}$ & 1.42 & 0.56 & $14.46 \mathrm{ab}$ \\
\hline \multicolumn{7}{|l|}{ Significance } \\
\hline Grass (G) & * & * & * & * & NS & * \\
\hline $\mathrm{N}$ fertilization rate $(\mathrm{N})$ & NS & NS & NS & NS & NS & NS \\
\hline $\mathrm{G} \times \mathrm{N}$ & NS & NS & NS & NS & NS & NS \\
\hline Year (Y) & $* * *$ & $* * *$ & $* *$ & NS & NS & $*$ \\
\hline$G \times Y$ & * & NS & NS & NS & NS & * \\
\hline $\mathrm{N} \times \mathrm{Y}$ & NS & NS & NS & NS & NS & NS \\
\hline $\mathrm{G} \times \mathrm{N} \times \mathrm{Y}$ & NS & NS & NS & NS & NS & NS \\
\hline
\end{tabular}

*Significant at $P=0.05$.

*Significant at $P=0.01$.

***Significant at $P=0.001$; NS, not significant.

${ }^{\text {a }}$ Numbers followed by different letters within a column are significantly different at $P=0.05$ by the least square means test.

were determined. After harvesting grain from the rest of the plot using a combine harvester, wheat residue (stems and leaves) was returned to the soil.

\subsection{Soil sampling for root biomass and water content}

After aboveground biomass harvest, soil samples containing roots were collected from the $0-120 \mathrm{~cm}$ depth from each grass plot using a truck-mounted hydraulic probe $(5 \mathrm{~cm}$ inside diameter) in October, 2011-2013 (Heggenstaller et al., 2009). Samples were collected randomly from four places within the plot, two between grass rows and two in the row where one was sampled between grasses and the other above the root crown. Samples were separated into 0-15, 15-30, $30-60,60-90$, and $90-120 \mathrm{~cm}$ increments to represent each depth, placed in plastic bags, and stored at $4{ }^{\circ} \mathrm{C}$ until roots were separated from the soil. About $50 \mathrm{~g}$ of root-free sample from each depth was collected before storage for determination of soil water content and other properties. A second undisturbed soil core from $0-120 \mathrm{~cm}$ was collected using the hydraulic probe as above for determining the bulk density. Samples were separated into $0-15,15-30,30-60,60-90$, and 90-120 cm depths, oven dried at $110^{\circ} \mathrm{C}$, and weighed, from which bulk density was calculated by dividing the weight of the oven-dried soil by the volume of the core.

The non-dried core soil samples were washed thoroughly with water in a hydropneumatic elutriator containing a $0.5-\mathrm{mm}$ screen for several hours until all silt and clay particles were removed (Smucker et al., 1982). Roots and sand particles left in the screen were transferred into a container and coarse and fine live roots were hand-picked using forceps. Roots that could not be picked by hand were separated by immersing the sand and root particles in a $2.2 \mathrm{~mol} \mathrm{~L}^{-1} \mathrm{NaCl}$ solution and floated roots were picked using forceps. Roots from four locations within the plot were composited by depth, oven-dried at $60{ }^{\circ} \mathrm{C}$ for $7 \mathrm{~d}$, and weighed to determine root biomass yield. Only live roots were used for biomass determination while dead roots and crop residue were discarded. Root biomass at 0-30, 0-60, 0-90, and 0-120 cm depths were determined by summing biomass from individual depths. Root/ shoot ratios at these depths were determined by dividing root biomass by shoot biomass. Gravimetric soil water content at root sampling was determined by oven drying $10 \mathrm{~g}$ root-free moist soil at $110{ }^{\circ} \mathrm{C}$ for $24 \mathrm{~h}$. Volumetric water content in the soil sample was determined by multiplying gravimetric water content by the soil bulk density. Spring wheat root biomass and soil water content in 2013 were also determined with the same procedures described above.

\subsection{Data analysis}

Data for root biomass, root/shoot ratio, and soil water content at a depth and shoot biomass for grasses were analyzed using the MIXED procedure of SAS after testing for homogeneity of variance (Littell et al., 2006). Grass, N fertilization rate, year, and their interactions were considered as fixed effects, and replication and replication $\times$ grass as random effects. Means were separated by using the least square means test when treatments and their interactions were significant (Littell et al., 2006). Correlation analysis was conducted between root biomass and soil water content to determine their relationship. Statistical significance was evaluated at $P \leq 0.05$, unless otherwise stated. Because of non-randomization of spring wheat plots with grass plots and incomplete year data (collected only in 2013), data for spring wheat could not be used for statistical analysis, but were shown only for descriptive comparison with perennial grasses.

\section{Results}

\subsection{Root biomass yield}

Root biomass yield of perennial grasses varied with grass species at all depths, except at $90-120 \mathrm{~cm}$, and varied with years at 0-15, 15-30, $30-60$, and $0-120 \mathrm{~cm}$ (Table 1 ). The grass $\times$ year interaction was significant at $0-15$ and $0-120 \mathrm{~cm}$. Averaged across $\mathrm{N}$ rates, intermediate wheatgrass and switchgrass had higher root biomass than smooth

Table 2

Interaction between grass species and year on perennial grass root biomass yield at 0-15 and $0-120 \mathrm{~cm}$ depths averaged across $\mathrm{N}$ fertilization rates.

\begin{tabular}{|c|c|c|c|c|c|c|}
\hline \multirow[t]{3}{*}{ Grass species $^{\mathrm{a}}$} & \multicolumn{6}{|c|}{ Root biomass $\left(\mathrm{Mg} \mathrm{ha}^{-1}\right)$} \\
\hline & \multicolumn{3}{|l|}{$0-15 \mathrm{~cm}$} & \multicolumn{3}{|l|}{$0-120 \mathrm{~cm}$} \\
\hline & 2011 & 2012 & 2013 & 2011 & 2012 & 2013 \\
\hline IW & $15.69 \mathrm{a}^{\mathrm{b}} \mathrm{A}^{\mathrm{c}}$ & $7.28 \mathrm{~B}$ & $7.62 B$ & $21.47 \mathrm{aA}$ & 13.03B & $14.64 \mathrm{~B}$ \\
\hline SB & $6.69 b$ & 7.64 & 7.33 & $11.67 \mathrm{~b}$ & 13.42 & 15.68 \\
\hline SG & $13.32 \mathrm{aA}$ & 6.89B & 7.65AB & $17.05 \mathrm{aA}$ & 11.24B & $12.54 \mathrm{AB}$ \\
\hline
\end{tabular}

${ }^{\text {a }}$ Perennial grasses are IW, intermediate wheatgrass; SB, smooth bromegrass; and SG, switchgrass.

${ }^{\mathrm{b}}$ Numbers followed by different lowercase letters within a column (year) between grasses in a depth are significantly different at $P=0.05$ by the least square means test.

${ }^{\mathrm{c}}$ Numbers followed by different uppercase letters within a row (grass) between years in a depth are significantly different at $P=0.05$ by the least square means test. 

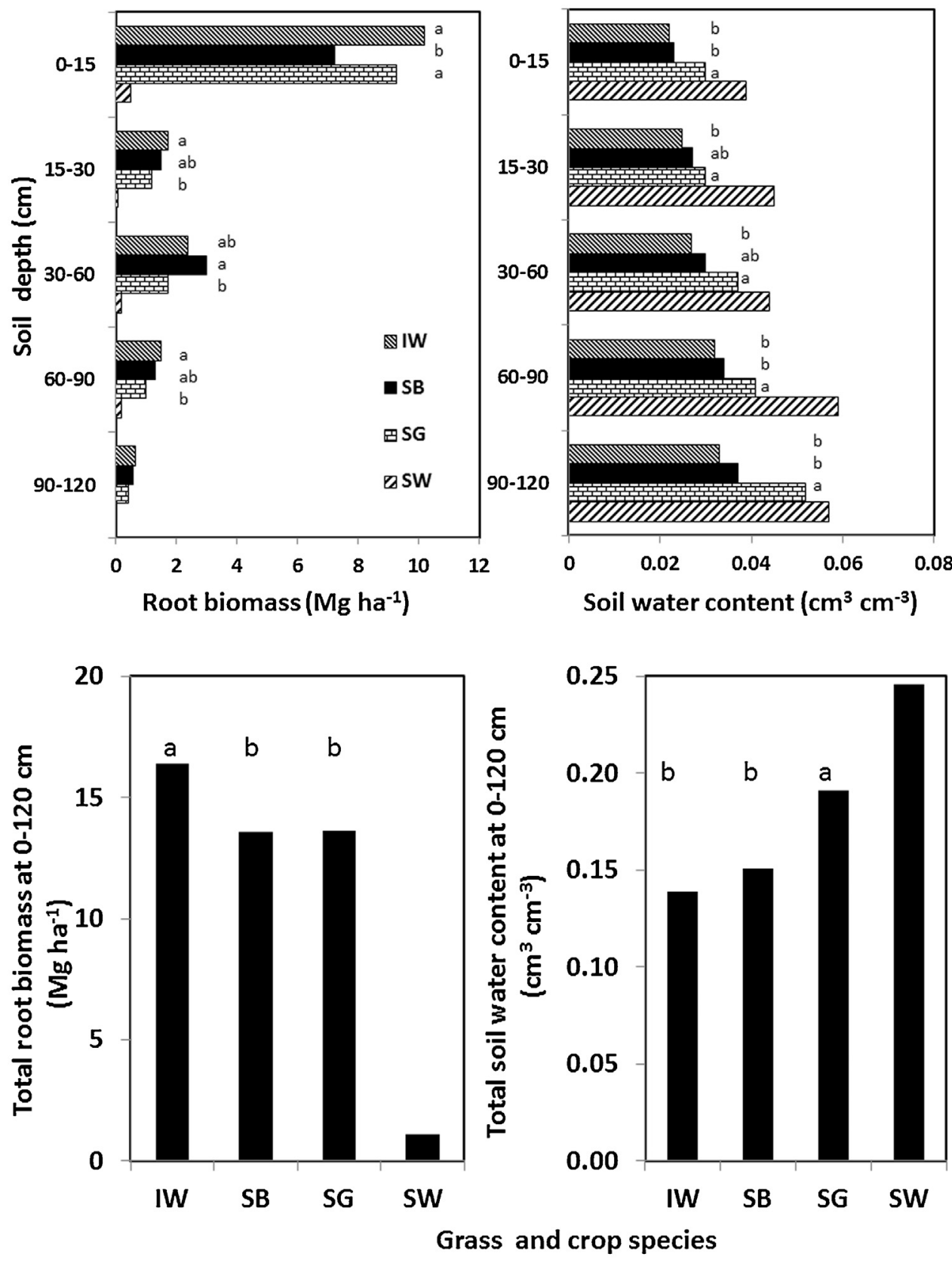

Fig. 1. Root biomass and soil water content at various depths in the $0-120 \mathrm{~cm}$ layer in perennial grasses averaged across $\mathrm{N}$ fertilization rates and years. Perennial grasses are IW, intermediate wheatgrass; SB, smooth bromegrass, and SG, switchgrass. Bars followed by different letters on the right are significantly different between perennial grasses at a soil depth at $P=0.05$ by the least square means test. Root biomass and soil water content in spring wheat (SW) in 2013 was included for comparison with perennial grasses and not used for data analysis.

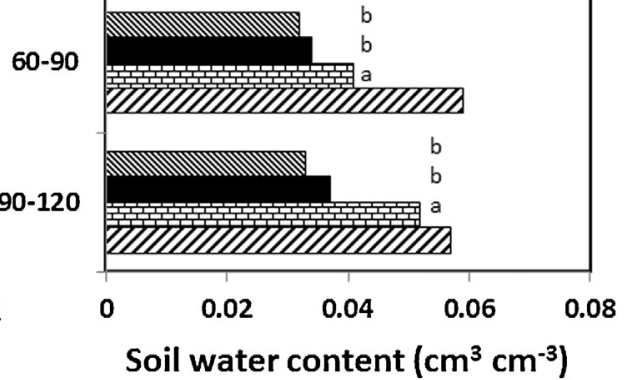

Fig. 2. Total root biomass and soil water content at the $0-120 \mathrm{~cm}$ depth in perennial grasses averaged across $\mathrm{N}$ fertilization rates and years. Perennial grasses are IW, intermediate wheatgrass; SB, smooth bromegrass, and SG, switchgrass. Bars followed by different letters on the top are significantly different between perennial grasses at $P=0.05$ by the least square means test. Total root biomass and soil water content at $0-120 \mathrm{~cm}$ in spring wheat (SW) in 2013 was included for comparison with perennial grasses and not used for data analysis. bromegrass at $0-15$ and $0-120 \mathrm{~cm}$ in 2011 (Table 2). At $0-15$ and 0-120 cm, root biomass was greater in 2011 than 2012 and 2013 with intermediate wheatgrass and greater in 2011 than 2012 with switchgrass. Averaged across $\mathrm{N}$ rates and years, root biomass decreased with increased depth (Fig. 1). Root biomass was greater at 30-60 cm than at $15-30,60-90$, and $90-120 \mathrm{~cm}$. While smooth bromegrass had lower root biomass than other grasses at $0-15 \mathrm{~cm}$, biomass was greater with intermediate wheatgrass than switchgrass at $15-30$ and $60-90 \mathrm{~cm}$. At 30-60 cm, smooth bromegrass, however, had greater biomass than switchgrass. Total root biomass at $0-120 \mathrm{~cm}$ was greater with intermediate wheatgrass than other grasses (Fig. 2). Nitrogen fertilization rate had no effect on root biomass. Root biomass at $0-15 \mathrm{~cm}$ ranged from $53 \%$ of the total biomass at $0-120 \mathrm{~cm}$ for switchgrass to $71 \%$ for smooth bromegrass. Root biomass for spring wheat also decreased with depth and ranged from $0.52 \mathrm{Mg} \mathrm{ha}^{-1}$ at $0-5 \mathrm{~cm}$ to $0.05 \mathrm{Mg} \mathrm{ha}^{-1}$ at $90-120 \mathrm{~cm}$. Averaged across grass species and $\mathrm{N}$ rates, root biomass varied with soil depths and years (Table 1).

\subsection{Shoot biomass yield}

Shoot biomass yield varied with grass species, $\mathrm{N}$ rates, and years, with significant interactions for grass $\times$ year and $\mathrm{N}$ rate $\times$ year (Table 3). Averaged across $\mathrm{N}$ rates, shoot biomass was greater with intermediate wheatgrass than smooth bromegrass and switchgrass in 2011, but was greater with switchgrass than intermediate wheatgrass and smooth bromegrass in 2013. Shoot biomass decreased from 2011 to 2012 and then increased in 2013 for all grasses. Shoot biomass was greater in 2011 than 2012 and 2013 with intermediate wheatgrass and smooth bromegrass, but was greater in 2013 than 2011 and 2012 with switchgrass. Averaged across $\mathrm{N}$ rates and years, shoot biomass was greater with intermediate wheatgrass than smooth bromegrass.

Shoot biomass, averaged across grass species, showed a quadratic response with $\mathrm{N}$ fertilization rate in 2011 and a linear response in 2013 $(P \leq 0.10)$, but a nonsignificant quadratic response in 2012 (Fig. 3). Shoot biomass was greater with 84 than 0 and $28 \mathrm{~kg} \mathrm{~N} \mathrm{ha}^{-1}$ in 2011 
Table 3

Interaction between grass species and year on perennial grass shoot biomass yield.

\begin{tabular}{|c|c|c|c|c|}
\hline \multirow[t]{2}{*}{ Grass species $^{\mathrm{a}}$} & \multicolumn{4}{|c|}{ Shoot biomass $\left(\mathrm{Mg} \mathrm{ha}^{-1}\right)$} \\
\hline & 2011 & 2012 & 2013 & Mean \\
\hline IW & $10.40 \mathrm{a}^{\mathrm{b}} \mathrm{A}^{\mathrm{c}}$ & $3.30 \mathrm{C}$ & $8.15 \mathrm{bB}$ & $7.42 \mathrm{a}$ \\
\hline SB & $7.91 \mathrm{bA}$ & $3.51 \mathrm{C}$ & $6.45 \mathrm{cB}$ & $5.96 \mathrm{~b}$ \\
\hline SG & $5.55 \mathrm{cB}$ & $4.09 \mathrm{C}$ & $9.32 \mathrm{aA}$ & $6.32 \mathrm{ab}$ \\
\hline Mean & $7.95 \mathrm{~A}^{\mathrm{d}}$ & $3.76 \mathrm{~B}$ & $7.98 \mathrm{~A}$ & \\
\hline \multicolumn{5}{|l|}{ Significance } \\
\hline Grass (G) & $*$ & & & \\
\hline $\mathrm{N}$ fertilization rate $(\mathrm{N})$ & $* *$ & & & \\
\hline $\mathrm{G} \times \mathrm{N}$ & NS & & & \\
\hline Year $(Y)$ & $* * *$ & & & \\
\hline$G \times Y$ & $* * *$ & & & \\
\hline $\mathrm{N} \times \mathrm{Y}$ & $*$ & & & \\
\hline $\mathrm{G} \times \mathrm{N} \times \mathrm{Y}$ & NS & & & \\
\hline
\end{tabular}

*Significant at $P=0.05$.

**Significant at $P=0.01$.

***Significant at $P=0.001$; NS, not significant.

a Perennial grasses are IW, intermediate wheatgrass; SB, smooth bromegrass; and SG, switchgrass.

${ }^{b}$ Numbers followed by different lowercase letters within a column (year) between grasses are significantly different at $P=0.05$ by the least square means test.

${ }^{\mathrm{c}}$ Numbers followed by different uppercase letters within a row (grass species) between years are significantly different at $P=0.05$ by the least square means test.

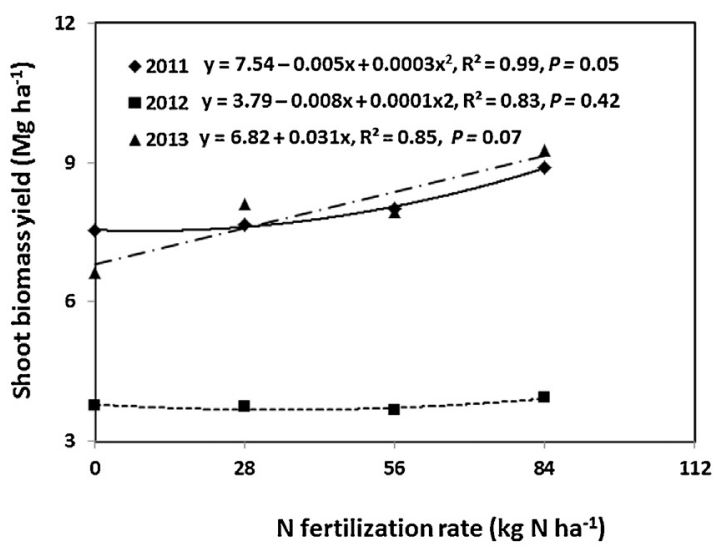

Fig. 3. Linear and quadratic responses of shoot biomass in perennial grasses with $\mathrm{N}$ fertilization rates from 2011 to 2013 averaged across grass species.

and 2013, but not different among $\mathrm{N}$ rates in 2012. Similarly, shoot biomass was greater in 2011 and 2013 than 2012, but similar between 2011 and 2013 (Table 3).

\subsection{Root/shoot ratio}

Differences in root and shoot growth of perennial grasses resulted in variation in root/shoot ratio among years, with a significant grass $\times$ year interaction at all depths (Table 4). Averaged across $\mathrm{N}$ rates, root/ shoot ratio at all depths was greater with switchgrass than other grasses in 2011, except with intermediate wheatgrass at 0-15 cm (Table 5). The root/shoot ratio at $0-90$ and $0-120 \mathrm{~cm}$ in 2012 and at $0-60,0-90$, and $0-120 \mathrm{~cm}$ in 2013 was greater with smooth bromegrass than switchgrass. The root/shoot ratio at all depths was normally greater in 2012 than 2011 and 2013 with intermediate wheatgrass and smooth bromegrass, but was greater in 2011 and 2012 than 2013 with switchgrass. Mean root/shoot ratios, averaged across $\mathrm{N}$ rates and years, were not different among grass species and ranged from $1.43-1.69$ at $0-15 \mathrm{~cm}$, $1.73-1.91$ at $0-30 \mathrm{~cm}, 2.20-2.28$ at $0-60 \mathrm{~cm}, 2.40-2.54$ at $0-90 \mathrm{~cm}$, and $2.43-2.65$ at $0-120 \mathrm{~cm}$. Root/shoot ratios for spring wheat in 2013 were $0.15,0.19,0.26,0.32$, and 0.33 at $0-15,0-30,0-60,0-90$, and $0-120 \mathrm{~cm}$, respectively. Averaged across grass species and $\mathrm{N}$ rates, the
Table 4

Root/shoot ratio of perennial grass (intermediate wheatgrass, smooth bromegrass, and switchgrass) at the $0-120 \mathrm{~cm}$ depth from 2011 to 2013 averaged across grass species and $\mathrm{N}$ fertilization rates.

\begin{tabular}{llllll}
\hline \multirow{2}{*}{ Year } & \multicolumn{3}{l}{ Root/shoot ratio } & & \\
\cline { 2 - 6 } & $0-15 \mathrm{~cm}$ & $0-30 \mathrm{~cm}$ & $0-60 \mathrm{~cm}$ & $0-90 \mathrm{~cm}$ & $0-120 \mathrm{~cm}$ \\
\hline 2011 & $1.63 \mathrm{a}^{\mathrm{a}}$ & $1.78 \mathrm{~b}$ & $2.04 \mathrm{~b}$ & $2.22 \mathrm{~b}$ & $2.23 \mathrm{~b}$ \\
2012 & $2.00 \mathrm{a}$ & $2.44 \mathrm{a}$ & $2.98 \mathrm{a}$ & $3.30 \mathrm{a}$ & $3.46 \mathrm{a}$ \\
2013 & $1.00 \mathrm{~b}$ & $1.23 \mathrm{c}$ & $1.69 \mathrm{~b}$ & $1.88 \mathrm{~b}$ & $1.93 \mathrm{~b}$ \\
Significance & & & & & \\
Grass (G) & $\mathrm{NS}$ & $\mathrm{NS}$ & $\mathrm{NS}$ & $\mathrm{NS}$ & $\mathrm{NS}$ \\
$\mathrm{N}$ fertilization rate (N) & $\mathrm{NS}$ & $\mathrm{NS}$ & $\mathrm{NS}$ & $\mathrm{NS}$ & $\mathrm{NS}$ \\
$\mathrm{G} \times \mathrm{N}$ & $\mathrm{NS}$ & $\mathrm{NS}$ & $\mathrm{NS}$ & $\mathrm{NS}$ & $\mathrm{NS}$ \\
Year (Y) & $* * *$ & $* * *$ & $* * *$ & $* * *$ & $* * *$ \\
$\mathrm{G} \times \mathrm{Y}$ & $* * *$ & $* * *$ & $* * *$ & $* * *$ & $* * *$ \\
$\mathrm{~N} \times \mathrm{Y}$ & $\mathrm{NS}$ & $\mathrm{NS}$ & $\mathrm{NS}$ & $\mathrm{NS}$ & $\mathrm{NS}$ \\
$\mathrm{G} \times \mathrm{N} \times \mathrm{Y}$ & $\mathrm{NS}$ & $\mathrm{NS}$ & $\mathrm{NS}$ & $\mathrm{NS}$ & $\mathrm{NS}$ \\
\hline
\end{tabular}

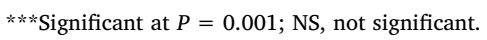

${ }^{\mathrm{a}}$ Numbers followed by different letters within a column are significantly different at $P=0.05$ by the least square means test.

root/shoot ratio at $0-30,0-60,0-90$, and $0-120 \mathrm{~cm}$ was greater in 2012 than 2011 and 2013 (Table 4).

\subsection{Soil water content}

Differences in soil water uptake among grasses resulted in significant effects of grass species and year on soil water content at grass harvest at all depths, with significant grass $\times$ year interaction at $0-15$, $60-90,90-120$, and $0-120 \mathrm{~cm}$ and $\mathrm{N}$ rate $\times$ year interaction at $0-15$ and $60-90 \mathrm{~cm}$ (Table 6). Averaged across $\mathrm{N}$ rates, soil water content was greater under switchgrass than intermediate wheatgrass and smooth bromegrass at $0-15,90-120$, and $0-120 \mathrm{~cm}$ in 2011 , and at $0-15,60-90$, and $90-120 \mathrm{~cm}$ in 2013 (Table 7). Soil water content was greater under switchgrass than intermediate wheatgrass at $0-120 \mathrm{~cm}$ in 2013. Soil water content was greater in 2013 than 2011 and 2012 for all grasses at all depths (Table 6), except for intermediate wheatgrass at $90-120 \mathrm{~cm}$ (Table 7). Averaged across $\mathrm{N}$ rates and years, soil water content under all grasses increased with increased depth (Fig. 1). Soil water content was greater under switchgrass than intermediate wheatgrass and smooth bromegrass at $0-15,60-90$, and $90-120 \mathrm{~cm}$, and greater under switchgrass than intermediate wheatgrass at $15-30$ and $30-60 \mathrm{~cm}$. Soil water content under annual spring wheat also increased with depth. Averaged across grass species, soil water content was greater with 28 and 84 than 0 and $56 \mathrm{~kg} \mathrm{~N}^{-1}$ at $0-15 \mathrm{~cm}$ in 2013 (Table 7). At 60-90 cm, soil water content was greater with 0 than 56 and $84 \mathrm{~kg} \mathrm{Nha}^{-1}$ in 2011, but was greater with 84 than $28 \mathrm{~kg} \mathrm{~N} \mathrm{ha}^{-1}$ in 2013. Root biomass correlated negatively with soil water content $(\mathrm{r}=-0.56, P=0.03, \mathrm{n}=15)$.

\section{Discussion}

The greater root biomass at $0-15 \mathrm{~cm}$ than at other depths for grasses and spring wheat (Fig. 1) shows the proliferation of roots at the surface soil likely linked to increased availability of soil water and nutrients as shown in other studies (Hodge, 2004; Skinner and Comas, 2010). About $70-90 \%$ of total root biomass of perennial forages to a $1 \mathrm{~m}$ depth occurs at the 0-20 cm layer (Steen, 1989). Bollinder et al. (2002) reported that root biomass at $0-15 \mathrm{~cm}$ was $55-64 \%$ of the total biomass for smooth bromegrass and $58-78 \%$ for switchgrass at $0-45 \mathrm{~cm}$ in eastern Canada, which is comparable to our values of $53-71 \%$ observed for perennial grasses at $0-60 \mathrm{~cm}$. Drying of soil at the surface, however, can increase root biomass at lower depth due to higher soil water content as suggested by Skinner (2008), which could be a possible reason for greater root biomass at $30-60 \mathrm{~cm}$ than at other depths, except at $0-15 \mathrm{~cm}$, in our experiment. Other possible reasons for greater root biomass at 
Table 5

Interaction between grass species and year on the root/shoot ratio of perennial grass at the $0-120$ soil depth averaged across $\mathrm{N}$ fertilization rates.

\begin{tabular}{|c|c|c|c|c|c|c|c|c|}
\hline \multirow[t]{3}{*}{ Grass species ${ }^{\mathrm{a}}$} & \multicolumn{8}{|c|}{ Root/shoot ratio } \\
\hline & \multicolumn{4}{|c|}{ Root biomass at $0-15 \mathrm{~cm}$} & \multicolumn{4}{|c|}{ Root biomass at $0-30 \mathrm{~cm}$} \\
\hline & 2011 & 2012 & 2013 & Mean & 2011 & 2012 & 2013 & Mean \\
\hline IW & $1.55 \mathrm{~b}^{\mathrm{b}} \mathrm{AB}^{\mathrm{c}}$ & $2.01 \mathrm{~A}$ & $0.98 \mathrm{~B}$ & 1.51 & $1.71 \mathrm{bB}$ & $2.50 \mathrm{~A}$ & $1.22 \mathrm{~B}$ & 1.81 \\
\hline SB & $0.87 \mathrm{bB}$ & $2.24 \mathrm{~A}$ & $1.17 \mathrm{~B}$ & 1.43 & $1.00 \mathrm{bB}$ & $2.74 \mathrm{~A}$ & $1.45 \mathrm{~B}$ & 1.73 \\
\hline SG & $2.47 \mathrm{aA}$ & $1.76 \mathrm{~B}$ & $0.85 \mathrm{C}$ & 1.69 & $2.63 \mathrm{aA}$ & $2.08 \mathrm{~A}$ & $1.02 \mathrm{~B}$ & 1.91 \\
\hline \multirow[t]{2}{*}{$\mathrm{SW}^{\mathrm{d}}$} & & & & 0.15 & & & & 0.19 \\
\hline & \multicolumn{4}{|c|}{ Root biomass at $0-60 \mathrm{~cm}$} & \multicolumn{4}{|c|}{ Root biomass at $0-90 \mathrm{~cm}$} \\
\hline IW & $1.92 \mathrm{bB}$ & $3.04 \mathrm{~A}$ & 1.65abB & 2.20 & $2.04 \mathrm{bB}$ & 3.41abA & $1.91 \mathrm{abB}$ & 2.45 \\
\hline SB & $1.28 \mathrm{bC}$ & $3.39 \mathrm{~A}$ & $2.18 \mathrm{aB}$ & 2.28 & $1.48 \mathrm{cC}$ & $3.76 \mathrm{aA}$ & $2.39 \mathrm{aB}$ & 2.54 \\
\hline SG & $2.93 \mathrm{aA}$ & $2.48 \mathrm{~A}$ & $1.24 \mathrm{bB}$ & 2.22 & $3.15 \mathrm{aA}$ & $2.71 \mathrm{bA}$ & $1.35 \mathrm{bB}$ & 2.40 \\
\hline \multirow[t]{2}{*}{ sw } & & & & 0.26 & & & & 0.32 \\
\hline & \multicolumn{4}{|c|}{ Root biomass at $0-120 \mathrm{~cm}$} & & & & \\
\hline IW & $2.12 \mathrm{bB}$ & 3.63abA & $1.89 \mathrm{abB}$ & 2.55 & & & & \\
\hline SB & $1.51 \mathrm{bC}$ & $3.92 \mathrm{aA}$ & $2.51 \mathrm{aB}$ & 2.65 & & & & \\
\hline SG & $3.07 \mathrm{aA}$ & $2.82 \mathrm{bA}$ & $1.39 \mathrm{bB}$ & 2.43 & & & & \\
\hline SW & & & & 0.33 & & & & \\
\hline
\end{tabular}

a Perennial grasses are IW, intermediate wheatgrass; SB, smooth bromegrass; and SG, switchgrass.

${ }^{\mathrm{b}}$ Numbers followed by different lowercase letters within a column (year) between grasses in a depth are significantly different at $P=0.05$ by the least square means test.

${ }^{\mathrm{c}}$ Numbers followed by different uppercase letters within a row (grass) between years in a depth are significantly different at $P=0.05$ by the least square means test.

${ }^{\mathrm{d}}$ SW is spring wheat. Root/shoot ratio of spring wheat measured in 2013 is shown for comparison only and not used for data analysis.

$30-60 \mathrm{~cm}$ could be due to increased nutrient availability, reduced soil compaction, and/or different soil texture that promoted root growth, but these factors were not examined in the study. Our proportion of $46 \%$ root biomass at $0-15 \mathrm{~cm}$ to total biomass at $0-120 \mathrm{~cm}$ for spring wheat was in between 36 and 52\% reported for spring wheat with or without $\mathrm{N}$ fertilization in western Canada (Campbell and de Jong, 2001).

The lower root biomass at $0-15$ and $0-120 \mathrm{~cm}$ with smooth bromegrass than other grasses in 2011 (Table 2) was a result of poor growth that also reduced shoot biomass as shown below, although the grass growing season (April-October) and annual precipitation in this year were greater than the 115-yr average (Table 8). Bollinder et al. (2002) found that smooth bromegrass yielded lower root biomass at $0-15 \mathrm{~cm}$ than most other grasses in initial years in eastern Canada. Perennial grasses usually have lower root biomass at the surface layer in initial years and reach maximum at 3-4 y later (Troughton, 1957; Bollinder et al., 2002). Bollinder et al. (2002) also observed increased root biomass for all grasses after several years of growth, primarily due to increased precipitation. In contrast, we observed greater root biomass for intermediate wheatgrass and switchgrass in 2011 due to above-average precipitation, after which they remained constant in successive years, although precipitation increased from 2012 to 2013 (Table 8). For smooth bromegrass, root biomass did not vary from 2011 to 2013. This suggests that precipitation plays an important role for root growth, especially during initial years. The reasons for similar root biomass at $0-15$ and $0-120 \mathrm{~cm}$ with all grasses in 2012 and 2013 were not clear, although growing season and annual precipitation were 190 and $181 \mathrm{~mm}$ greater in 2013 than 2012. At $30-60 \mathrm{~cm}$, root biomass, however, increased from 2012 to 2013 (Table 1). More than three years of study may be needed to detect changes in root biomass of perennial grasses over time, as root biomass changes with age of perennial grasses (Troughton, 1957; Bollinder et al., 2002).

Our average root biomass of 10.3 and $12.1 \mathrm{Mg} \mathrm{ha}^{-1}$ for smooth bromegrass and switchgrass, respectively, at $0-30 \mathrm{~cm}$ were slightly higher than 9.1 and $8.3 \mathrm{Mg} \mathrm{ha}^{-1}$ reported by Bollinder et al. (2002) in eastern Canada. In contrast, our root biomass of $15.1 \mathrm{Mg} \mathrm{ha}^{-1}$ at 0-90 cm for smooth bromegrass with or without $\mathrm{N}$ fertilization was between the values of $14.8-22.2 \mathrm{Mg} \mathrm{ha}^{-1}$ observed in North Dakota (Power, 1988). However, our root biomass of $13.6 \mathrm{Mg} \mathrm{ha}^{-1}$ at $0-120 \mathrm{~cm}$ for switchgrass with or without $\mathrm{N}$ fertilization was lower than

Table 6

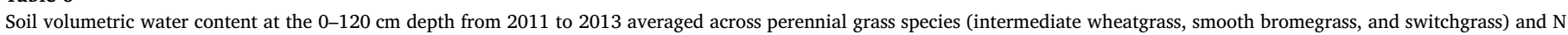
fertilization rates.

\begin{tabular}{|c|c|c|c|c|c|c|}
\hline \multirow[t]{2}{*}{ Year } & \multicolumn{6}{|c|}{ Volumetric water content $\left(\mathrm{cm}^{3} \mathrm{~cm}^{-3}\right)$} \\
\hline & $0-15 \mathrm{~cm}$ & $15-30 \mathrm{~cm}$ & $30-60 \mathrm{~cm}$ & $60-90 \mathrm{~cm}$ & $90-120 \mathrm{~cm}$ & $0-120 \mathrm{~cm}$ \\
\hline 2011 & $0.020 \mathrm{~b}^{\mathrm{a}}$ & $0.021 b$ & $0.023 b$ & $0.030 \mathrm{~b}$ & $0.039 b$ & $0.133 b$ \\
\hline 2012 & $0.014 \mathrm{c}$ & $0.019 b$ & $0.023 b$ & $0.026 \mathrm{~b}$ & $0.031 \mathrm{c}$ & $0.113 c$ \\
\hline 2013 & $0.040 \mathrm{a}$ & $0.043 \mathrm{a}$ & $0.048 \mathrm{a}$ & $0.050 \mathrm{a}$ & $0.052 \mathrm{a}$ & $0.233 \mathrm{a}$ \\
\hline \multicolumn{7}{|l|}{ Significance } \\
\hline Grass (G) & $*$ & $*$ & $*$ & $*$ & $* *$ & $* *$ \\
\hline $\mathrm{N}$ fertilization rate $(\mathrm{N})$ & NS & NS & NS & NS & NS & NS \\
\hline $\mathrm{G} \times \mathrm{N}$ & NS & NS & NS & NS & NS & NS \\
\hline Year (Y) & $* * *$ & $* * *$ & $* * *$ & $* * *$ & $* * *$ & $* * *$ \\
\hline $\mathrm{G} \times \mathrm{Y}$ & $*$ & NS & NS & $* *$ & $*$ & $* *$ \\
\hline $\mathrm{N} \times \mathrm{Y}$ & $*$ & NS & NS & $*$ & NS & NS \\
\hline $\mathrm{G} \times \mathrm{N} \times \mathrm{Y}$ & NS & NS & NS & NS & NS & NS \\
\hline
\end{tabular}

*Significant at $P=0.05$.

** Significant at $P=0.01$.

$* *$ Significant at $P=0.001$; NS, not significant.

${ }^{\text {a }}$ Numbers followed by different letters within a column are significantly different at $P=0.05$ by the least square means test. 
Table 7

Interactions between perennial grass species, $\mathrm{N}$ fertilization rate, and year on soil volumetric water content at $0-15,60-90,90-120$, and $0-120 \mathrm{~cm}$ depths.

\begin{tabular}{|c|c|c|c|c|c|c|c|}
\hline \multirow[t]{3}{*}{ Grass species $^{\mathrm{a}}$} & \multirow{3}{*}{$\begin{array}{l}\mathrm{N} \text { fertilization rate } \\
\left(\mathrm{kg} \mathrm{N} \mathrm{ha}^{-1}\right)\end{array}$} & \multicolumn{6}{|c|}{ Volumetric water content $\left(\mathrm{cm} \mathrm{cm}^{-3}\right)$} \\
\hline & & \multicolumn{3}{|l|}{$0-15 \mathrm{~cm}$} & \multicolumn{3}{|l|}{$60-90 \mathrm{~cm}$} \\
\hline & & 2011 & 2012 & 2013 & 2011 & 2012 & 2013 \\
\hline IW & & $0.015 \mathrm{~b}^{\mathrm{b}} \mathrm{B}^{\mathrm{c}}$ & $0.014 \mathrm{~B}$ & $0.037 \mathrm{bA}$ & $0.027 \mathrm{~B}$ & $0.027 \mathrm{~B}$ & $0.041 \mathrm{bA}$ \\
\hline SB & & $0.020 \mathrm{bB}$ & $0.013 \mathrm{C}$ & $0.035 \mathrm{bA}$ & $0.032 \mathrm{~B}$ & $0.023 \mathrm{C}$ & $0.045 \mathrm{bA}$ \\
\hline \multirow[t]{2}{*}{ SG } & & $0.027 \mathrm{aB}$ & $0.014 \mathrm{C}$ & $0.049 \mathrm{aA}$ & $0.033 \mathrm{~B}$ & 0.027B & $0.062 \mathrm{aA}$ \\
\hline & & $90-120 \mathrm{~cm}$ & & & $0-120 \mathrm{~cm}$ & & \\
\hline IW & & $0.030 \mathrm{~b}$ & 0.031 & $0.039 b$ & $0.108 \mathrm{bB}$ & $0.115 B$ & $0.193 \mathrm{bA}$ \\
\hline SB & & $0.035 \mathrm{bB}$ & $0.029 B$ & $0.048 \mathrm{bA}$ & $0.133 \mathrm{bB}$ & $0.121 \mathrm{~B}$ & $0.217 \mathrm{abA}$ \\
\hline \multirow[t]{6}{*}{ SG } & & $0.053 \mathrm{aA}$ & $0.034 \mathrm{~B}$ & $0.069 \mathrm{aA}$ & $0.164 \mathrm{aB}$ & $0.104 \mathrm{C}$ & $0.289 \mathrm{aA}$ \\
\hline & & $0-15 \mathrm{~cm}$ & & & $60-90 \mathrm{~cm}$ & & \\
\hline & 0 & $0.019 \mathrm{~B}$ & $0.015 \mathrm{~B}$ & $0.034 \mathrm{bA}$ & $0.038 \mathrm{aB}$ & $0.027 \mathrm{C}$ & $0.050 \mathrm{abA}$ \\
\hline & 28 & $0.019 \mathrm{~B}$ & $0.014 \mathrm{~B}$ & $0.048 \mathrm{aA}$ & $0.032 \mathrm{abAB}$ & $0.025 B$ & $0.041 \mathrm{bA}$ \\
\hline & 56 & $0.022 \mathrm{~B}$ & $0.013 \mathrm{C}$ & $0.036 \mathrm{bA}$ & $0.027 \mathrm{bB}$ & $0.027 \mathrm{~B}$ & $0.050 \mathrm{abA}$ \\
\hline & 84 & $0.021 \mathrm{~B}$ & $0.013 \mathrm{C}$ & $0.043 \mathrm{aA}$ & $0.027 \mathrm{bB}$ & $0.025 B$ & $0.058 \mathrm{aA}$ \\
\hline
\end{tabular}

a Perennial grasses are IW, intermediate wheatgrass; SB, smooth bromegrass; and SG, switchgrass.

b Numbers followed by different lowercase letters within a column (year) between grasses in a depth are significantly different at $P=0.05$ by the least square means test.

${ }^{\mathrm{c}}$ Numbers followed by different uppercase letters within a row (grass or $\mathrm{N}$ fertilization rate) between years in a depth are significantly different at $P=0.05$ by the least square means test.

Table 8

Monthly total precipitation (mm) from 2011 to 2013 at the experimental site.

\begin{tabular}{lllll}
\hline Month & 2011 & 2012 & 2013 & 115 -yr average \\
\hline January & 2 & 0 & 2 & 9 \\
February & 4 & 2 & 1 & 5 \\
March & 7 & 4 & 12 & 14 \\
April & 35 & 27 & 9 & 22 \\
May & 172 & 58 & 121 & 51 \\
June & 71 & 82 & 121 & 71 \\
July & 42 & 26 & 49 & 68 \\
August & 25 & 12 & 73 & 34 \\
September & 17 & 0 & 41 & 29 \\
October & 16 & 46 & 9 & 22 \\
November & 2 & 10 & 6 & 11 \\
December & 4 & 3 & 9 & 10 \\
April-October & 378 & 251 & 423 & 297 \\
January-December & 397 & 271 & 453 & 341 \\
\hline
\end{tabular}

16-29 $\mathrm{Mg} \mathrm{ha}^{-1}$ at $0-100 \mathrm{~cm}$ reported by Heggenstaller et al. (2009) in Iowa. Differences in soil and climatic conditions, management practices, depth of soil sampling, and age of grasses may have resulted in variations in root biomass of perennial grasses among regions and years of study. While our values for root biomass for smooth bromegrass were similar to identical soil (loam soil) and climatic conditions (annual precipitation $350-400 \mathrm{~mm}$ ) in eastern Montana and central North Dakota, our values for greater root biomass for smooth bromegrass and switchgrass than those reported in eastern Canada could be a result of sandy loam soil that holds less water than loam soil in our study. In contrast, our values for lower root biomass for switchgrass than those reported in Iowa were probably due to reduced annual precipitation, as Iowa receives $515 \mathrm{~mm}$ more annual precipitation than eastern Montana.

Overall greater root biomass of intermediate wheatgrass at $0-120 \mathrm{~cm}$ (Fig. 2) suggests that intermediate wheatgrass may perform well and provide more $\mathrm{C}$ inputs for soil $\mathrm{C}$ sequestration than other grasses under dryland conditions in the northern Great Plains, USA. Higher root biomass of intermediate wheatgrass than winter wheat to $>1 \mathrm{~m}$ depth has been reported (Lubofsky, 2016). In our study, spring wheat had a total root biomass of $1.1 \mathrm{Mg} \mathrm{ha}^{-1}$ at $0-120 \mathrm{~cm}$ compared with 13.6-16.4 $\mathrm{Mg} \mathrm{ha}^{-1}$ for perennial grasses.

Differences in the growth of grasses among years may have resulted in variations in shoot biomass yield among grass species (Table 3). Although the growing season and annual precipitation were above the 115-yr average in 2011 and 2013 (Table 8), it is likely that intermediate wheatgrass established quickly soon after planting, resulting in higher shoot biomass than other grasses in 2011. Growth of intermediate wheatgrass may have declined in successive years, resulting in lower shoot biomass than switchgrass in 2013. The reverse was true for switchgrass which had lower shoot biomass in 2011, but had greater biomass than other grasses in successive years. In 2012, however, below-average precipitation resulted in decline of shoot biomass for all grasses (Tables 3 and 8). Our trend of shoot biomass with year for intermediate wheatgrass was in contrast to that reported by Culman et al. (2013) in Michigan, but intermediate wheatgrass outperformed switchgrass in shoot biomass yield in South Dakota (Lee et al., 2009) and North Dakota (Xue et al., 2011), a case similar to that observed in our study. It is possible that intermediate wheatgrass performs better in North Dakota and South Dakota due to lower precipitation than in Michigan. Bollinder et al. (2002) reported that shoot biomass was higher with smooth bromegrass and lower with switchgrass than most other grasses in eastern Canada. Our shoot biomass yields of 3.3-10.4 $\mathrm{Mg}$ ha $^{-1}$ for intermediate wheatgrass was similar to or lower than 3.9-17.1 $\mathrm{Mg} \mathrm{ha}^{-1}$ observed in Michigan (Culman et al., 2013). Similarly, our shoot biomass yields of $3.5-7.9 \mathrm{Mg} \mathrm{ha}^{-1}$ for smooth bromegrass and 4.1-9.3 $\mathrm{Mg} \mathrm{ha}^{-1}$ for switchgrass were similar to or lower than 9.7-12.5 Mg ha ${ }^{-1}$ for smooth bromegrass and 6.2-6.9 $\mathrm{Mg} \mathrm{ha}^{-1}$ for switchgrass reported by Bollinder et al. (2002) in eastern Canada.

Below-average precipitation not only reduced shoot biomass at all $\mathrm{N}$ rates in 2012 than other years, but also resulted in non-significant response of shoot biomass with $\mathrm{N}$ rate in that year (Table 3, Fig. 3), suggesting that adequate soil water content is needed to increase grass shoot biomass yield with increased $\mathrm{N}$ rates. Results suggest that shoot biomass may further increase with increased $\mathrm{N}$ rates during years with above-average precipitation. Several researchers (Vogel et al., 2002; Heggenstaller et al., 2009) reported that maximum switchgrass shoot biomass yield reached at $120-140 \mathrm{~kg} \mathrm{~N} \mathrm{ha}^{-1}$ in Iowa and Nebraska, which had 2.5 and 2.2 times, respectively, more annual precipitation than in eastern Montana. Power (1988) also observed increased shoot biomass yield with increased $\mathrm{N}$ rate for smooth bromegrass in North Dakota.

Roots appeared to grow more than shoots in switchgrass compared to other grasses in 2011 with above-average growing season precipitation, as root/shoot ratio was higher with this grass (Tables 2 and 
5). In successive years, however, more roots grew below $90 \mathrm{~cm}$ in smooth bromegrass (Fig. 1), resulting in greater root/shoot ratios with this grass than switchgrass at $0-90$ and $0-120 \mathrm{~cm}$ in 2012 and 2013, regardless of whether the growing season precipitation was below or above the average. This indicates that biomass allocation in above- and belowground components vary with grass species and years, with more allocation in below- than aboveground component with switchgrass in initial years, with the reverse trend occurring with smooth bromegrass in successive years. This is in contrast to that observed by Bollinder et al. (2002) in eastern Canada, who reported that the root/shoot ratio was not significantly different between switchgrass and smooth bromegrass, although switchgrass tended to have a higher ratio. As switchgrass is warm-season grass and smooth bromegrass cool-season grass, it may be possible that above- and belowground growth of switchgrass may differ in eastern Montana and eastern Canada due to differences in soil and climatic conditions. Both root and shoot of perennial grasses may grow in the same proportion in the sandy loam soil with annual precipitation of $442 \mathrm{~mm}$, resulting in similar root/shoot ratios among perennial grasses in eastern Canada compared with different proportions in the loamy soil and $350 \mathrm{~mm}$ precipitation in eastern Montana. Nitrogen rate did not influence the root/shoot ratio of grasses, suggesting that both shoot and root grow equally with increased N rates. Similar results have been reported for switchgrass by Heggenstaller et al. (2009) in Iowa, but the ratio decreased with increased N rates for smooth bromegrass in North Dakota (Power, 1988).

Our root/shoot ratios of $1.00-2.74$ for smooth bromegrass and $1.02-2.63$ for switchgrass at $0-30 \mathrm{~cm}$ were greater than the ranges $0.52-1.16$ and $0.76-1.72$, respectively, observed for these grasses by Bollinder et al. (2002) in eastern Canada. Power (1988) reported root/ shoot ratios of 3.70-14.29 at 0-90 cm for smooth bromegrass with or without $\mathrm{N}$ fertilization in North Dakota, which were substantially greater than 1.48-3.76 observed in our study. Heggenstaller et al. (2009) found root/shoot ratios of 2.10-2.50 for switchgrass with or without $\mathrm{N}$ fertilization at $0-100 \mathrm{~cm}$ in Iowa which were within $1.39-3.07$ at $0-120 \mathrm{~cm}$ found in our study. Root/shoot ratios of grasses differ among regions due to variability in soil and climatic conditions, age and growth of the plant, depth of soil sampling, management practices, and root separation methods (Bollinder et al., 2002). Our mean root/shoot ratios of 1.43-2.65 for perennial grasses at various soil depths were, however, 8.5-9.0 times greater than that observed for annual spring wheat $(0.15-0.33)$ due to greater root than shoot biomass, a case similar to those reported by Bollinder et al. $(1997,2002)$ and Campbell and de Jong (2001).

The increased root/shoot ratio of intermediate wheatgrass and smooth bromegrass at all depths in 2012 than in 2011 and 2013 (Table 5) shows that more biomass was allocated to roots than shoots during the year with below-average precipitation in these grasses. Although not significant, root biomass was greater, but shoot biomass was lower, with intermediate wheatgrass and smooth bromegrass than switchgrass in 2012 (Tables 2 and 3). Skinner and Comas (2010) found that the root/shoot ratio of grasses increased during water stress due to limited effect of the stress on root compared with shoot growth. Skinner (2008) reported that soil drying at the surface layer increased root growth at lower depths where soil water content was higher, but reduced shoot growth, thereby increasing root/shoot ratio of perennial grasses during drought conditions. This appeared to be true in the current study for intermediate wheatgrass and smooth bromegrass which had higher root biomass than switchgrass below $15 \mathrm{~cm}$ (Fig. 1). It is likely that roots of cool-season grasses, such as intermediate wheatgrass and smooth bromegrass, compared with shoots grow earlier than warm-season grasses, such as switchgrass, thereby increasing the root/ shoot ratio at subsurface layers. This was certainly the case with intermediate wheatgrass and smooth bromegrass during the year with below-average precipitation (2012).

The lower soil water content at surface than subsurface layers was a result of greater acquisition of water by roots from upper soil layers during grass growth. Roots proliferated by increasing water uptake near the surface layer (Fig. 1). Soil water content increased with depth as root biomass decreased, likely due to reduced water uptake. Except during periods with abundant precipitation, most water from precipitation may not reach to subsurface layers due to uptake by roots at the surface layer, especially in semiarid regions. There was a significant negative correlation between root biomass and soil water content ( $\mathrm{r}=-0.56, P=0.03, \mathrm{n}=15$ ). While this supports a relationship between root biomass and water uptake, the moderate level of the correlation was probably because of the fact that only $10-30 \%$ of the total root system is actually engaged in water uptake (Robinson, 1991). Water may also be lost through evaporation, runoff, and leaching (Pierret et al., 2007). Deep roots often appear during drought to extract water from deeper soil layers (Skinner and Comas, 2010). The lower root biomass in annual spring wheat was likely related to greater soil water content at all depths, a pattern not present in perennial grasses (Fig. 1).

The increased soil water content under switchgrass than other grasses at most soil depths in 2011 and 2013 (Table 7) indicates that switchgrass may not be as effective in extracting water from the soil as other grasses, probably because of decreased root biomass at lower soil depths. Although root biomass was similar between switchgrass and intermediate wheatgrass at $0-15 \mathrm{~cm}$, root biomass was lower in switchgrass than intermediate wheatgrass and smooth bromegrass at 15-30, 30-60, and 60-90 cm layers (Fig. 1). Because switchgrass is a warm-season grass, it is likely that slower growth of roots in the spring may permit more water to accumulate in deeper soil layers, thereby increasing soil water content under switchgrass compared to other two cool-season grasses. Roots at deep layer can extract significant amounts of water, especially during drought (Skinner, 2008; Skinner and Comas, 2010). The greater soil water content in 2013 than other years (Tables 6 and 7) was due to higher precipitation (Table 8).

As root biomass was not affected by $\mathrm{N}$ rates in our study, it was unclear why $\mathrm{N}$ rates had variable effect on soil water content at various depths. Shoot biomass yield increased with N rates in 2011 and 2013 (Fig. 3), but there was no significant relationship between $\mathrm{N}$ rate and soil water content. It may be possible that heterogeneity in soil organic matter content, soil texture, and presence or absence of roots in the soil profile resulted in various soil water content at various depths.

\section{Conclusions}

Root biomass at various soil depths and shoot biomass of perennial grasses varied with grass species and years. Smooth bromegrass had lower root and shoot biomass than intermediate wheatgrass and switchgrass. The root/shoot ratio, however, was similar among grass species. Both root and shoot biomass responded well during years with above-average precipitation, but roots grew more than shoots during years with below-average precipitation, resulting in higher root/shoot ratio. Nitrogen fertilization increased shoot biomass, but had little effect on root biomass and the root/shoot ratio compared with no $\mathrm{N}$ fertilization. Root biomass decreased, but soil water content increased with increased depth. Switchgrass was less effective in removing soil water from the profile than intermediate wheatgrass and smooth bromegrass. Because of greater root biomass, intermediate wheatgrass can provide more $\mathrm{C}$ inputs for soil $\mathrm{C}$ sequestration than other grasses. Low root than shoot biomass substantially reduced the root/shoot ratio of annual spring wheat, likely related to soil water content. More than three years of study, however, may be needed to evaluate root and shoot biomass of perennial grasses with different $\mathrm{N}$ fertilization rates, as successive years' results indicated that switchgrass continued to outperform in shoot biomass compared with other cool-season grasses.

\section{Acknowledgements}

We acknowledge the excellent support provided by Joy Barsotti, 
Michael Johnson, and Rene France for field work and Joy Barsotti, Jana Seright, Emily Reese, and Lyn Solberg for soil, root, and plant sampling in the field and analysis in the laboratory.

\section{References}

Amato, M., Pardo, A., 1994. Root length and biomass losses during sample preparation with different screen mesh sizes. Plant Soil 161, 299-303.

Bollinder, M.A., Angers, D.A., Dubuc, J.P., 1997. Estimating shoot to root ratios and annual carbon inputs in soils for cereal crops. Agric. Ecosyst. Environ. 63, 61-66.

Bollinder, M.A., Angers, D.A., Belanger, G., Michaud, R., Lavadiere, M.R., 2002. Root biomass and shoot to root ratios of perennial forage crops in eastern Canada. Can. J. Plant Sci. 82, 731-737.

Bray, J.R., 1963. Root production and estimation of net productivity. Can. J. Bot. 41, $65-72$.

Campbell, C.A., de Jong, R., 2001. Root-to-straw ratios - influence of moisture and rate of N fertilizer. Can. J. Soil Sci. 81, 39-43.

Culman, S.W., Snapp, S.S., Ollenburger, M., Basso, B., de Haan, L.R., 2013. Soil and water quality rapidly respond to the perennial grain Kernza wheatgrass. Agron. J. 105, 735-744.

Gale, W.J., Cambardella, C.A., Bailey, T.B., 2000. Root-derived carbon and the formation and stabilization of agregates. Soil Sci. Soc. Am. J. 64, 201-207.

Hawes, M.C., Bengough, G., Cassab, G., Ponce, G., 2003. Root caps and rhizosphere. J. Plant Growth Regul. 2, 352-367.

Heggenstaller, A.H., Moore, K.J., Liebman, M., Anex, R.P., 2009. Nitrogen influences biomass and nutrient partitioning by perennial warm-season grasses. Agron. J. 101, 1363-1371.

Hodge, A., 2004. The plastic plant. Root responses to heterogeneous supply of nutrients. New Phytol. 162, 9-24.

Ibrahim, M., Hong, C.O., Singh, S., Kumar, S., Osborne, S., Owens, V., 2016. Switchgrass biomass quality as affected by nitrogen rate, harvest time, and storage. Agron. J. 109, $1-11$.

Lee, D., Owens, V.N., Boe, A., Koo, B., 2009. Biomass and seed yields of big bluestem, switchgrass, and intermediate wheatgrass in response to manure and harvest timing at two topographic positions. GCB Bioenergy 1, 171-179.

Littell, R.C., Milliken, G.A., Stroup, W.W., Wolfinger, R.D., Schabenberger, O., 2006. SAS for Mixed Models. SAS Inst. Inc., Cary, NC.

Lubofsky, E., 2016. The promise of perennials. Working through the challenges of perennial grain crop development. CSA News 61, 5-7. November 2016. ASA/CSSA SSSA, Madison, WI

Merrill, S.D., Tanaka, D.L., Hanson, J.D., 2002. Root length growth of eight crop species in Haplustoll soils. Soil Sci. Soc. Am. J. 66, 913-923.

Mo, G., Nie, D., Kirkham, M.R., He, H., Ballou, L.K., Caldwell, F.W., Kanemasu, E.T., 1992. Root and shoot weights in a tallgrass prairie under elevated carbon dioxide.
Environ. Exp. Bot. 32, 103-201.

Mortimer, S.R., 1992. Root length/leaf area ratios of chalk grassland perennials and their importance for competitive interactions. J. Veg. Sci. 3, 665-672.

Nguyen, C., 2003. Rhizodeposition of organic carbon by plants. Mechanisms and control. Agronomie 23, 375-396.

Norby, R.J., Cotrufo, M.F., 1998. A question of litter quality. Nature 396, 17-18.

Pacala, S., Solocolow, R., 2004. Stabilization wedges: solving the climate problem for the next 50 years with current technologies. Science 305, 968-972.

Paustian, K., Collins, H.P., Paul, E.A., 1997. Management controls on soil carbon. In: Paul, E.A., Paustian, K., Cole, C.V. (Eds.), Soil Organic Matter in Temperate Agroecosystems Long-term Experiments in North America. CRC Press Inc., New York, NY, pp. 15-49.

Pierret, A., Doussan, C., Capowlez, Y., Bastardie, F., Pages, L., 2007. Root functional architecture: a framework for modeling the interplay between roots and soil. Vad. Zone J. 6, 269-281.

Power, J.F., 1988. Seasonal changes in smooth bromegrass top and root growth and fate of fertilizer nitrogen. Agron. J. 80, 740-745.

Puget, P., Drinkwater, L.E., 2001. Short-term dynamics of root- and shoot-derived carbon from a leguminous green manure. Soil Sci. Soc. Am. J. 65, 771-779.

Robinson, D., 1991. Roots and resource fluxes in plants and communities. In: Atkinson, D. (Ed.), Plant Root Growth: An Ecological Perspective Spec. Pub. No. 10. British Ecological Society. Blackwell Scientific, Oxford, UK, pp. 103-130.

Skinner, R.H., Comas, L.H., 2010. Root distribution of temperate forage species subjected to water and nitrogen stress. Crop Sci. 50, 2178-2185.

Skinner, R.H., 2008. Yield, root growth, and soil water content in drought-stressed pasture mixtures containing chicory. Crop Sci. 48, 380-388.

Smucker, A.J.M., McBurney, S.L., Srivastava, A.K., 1982. Quantitative separation of roots from compacted soil profile by hydropneumatic elutriation system. Agron. J. 74, 500-503.

Steen, E., 1989. Root biomass in timothy and red clover leys estimated by soil coring and mesh bags. J. Agric. Sci. (Camb.) 113, 241-247.

Stone, L.R., Goodrum, D.E., Jaafar, M.N., Khan, A.H., 2001. Rooting front and water depletion depths in grain sorghum and sunflower. Agron. J. 93, 1105-1110.

Troughton, A., 1957. The underground organs of herbage grasses. Bull. 44. Commonwealth Bureau of Pastures and Field Crops. Hurley, UK.

United States Department of Energy (USDOE), 2007. Alternative fuel transportation program: Replacement fuel goal modification, Fed. Registr. 72(50). Rules and regulations. Office of Energy Efficiency and Renewable Energy, Washington, DC.

van Nordwijk, M., Floris, J., de Jager, A., 1987. Sampling schemes for estimating root density distribution in cropped fields. Neth. J. Agric. Res. 33, 241-262.

Vogel, K.P., Brejda, J.J., Walters, D.T., Buxton, D.W., 2002. Switchgrass biomass production in the Midwest USA: Harvest and nitrogen management. Agron. J. 94, 413-420.

Xue, Q., Nyren, P.E., Wang, G., Eriksmen, E., Bradbury, G., Halvorson, M., 2011. Biomass composition of perennial grasses in biofuel production in North Dakota USA. Biofuels 2, 515-528. 